\title{
Chapter 2 \\ Spatial Mobility of Knowledge: \\ Communicating Different Categories of Knowledge
}

\author{
Peter Meusburger
}

[D]irect communication between the adherents of different thought styles is impossible.

(Fleck 1935/1979, p. 36)

Learning processes, spatial mobility of knowledge, and, accordingly, the spatial diffusion of social and technical innovations belong to the basic issues of human civilizations. The exchange of knowledge and information over distances is an indispensable prerequisite for the emergence, coordination, and functioning of complex social systems based on division of labor. Knowledge exchange, education, research, creativity, innovative activities, and in-migration of talent shape regional economies and the global competitiveness of areas.

Unfortunately, a considerable part of research about knowledge spillovers, knowledge sharing, knowledge exchange, knowledge management, knowledge governance, and territorial knowledge dynamics oversimplifies the communication process of various categories of knowledge. Many categories and grades of knowledge are not as mobile in the spatial dimension as some authors assume. Depending on the category of knowledge, the communication of knowledge ${ }^{1}$ between people, institutions, different epistemic communities, and locations can be a highly complex process. Very few authors seem to be interested in the questions of why the transfer of knowledge from A to B did not come about, was delayed for years, or failed; why various categories of knowledge travel at different speeds; why the

This chapter contains some arguments, paragraphs, and figures of an earlier publication (Meusburger, P., 2009b). Those parts of this paper published in 2009 are reprinted with permission of the editors of disP-The Planning Review.

${ }^{1}$ It will be shown in later paragraphs that only information or messages can be transmitted. It depends on the recipient whether he or she is able to understand the information and integrate it into the existing knowledge base. Nevertheless, the expression "knowledge" is used in order to refer to the existing literature.

P. Meusburger $(\bowtie)$

Department of Geography, Heidelberg University, Heidelberg, Germany

e-mail: peter.meusburger@uni-heidelberg.de

H. Jöns et al. (eds.), Mobilities of Knowledge, Knowledge and Space 10, 
mobility of higher grades of knowledge is so selective in the spatial dimension; and which factors, interventions, language barriers, and psychological processes prevent, impede, or modify the communication process between the sources of knowledge and the recipients of information.

In order to avoid misunderstandings about the mobility of knowledge, it is necessary to distinguish different categories of knowledge transfer, such as the mobility of persons; knowledge exchange between scholars; knowledge transfer where the use of knowledge is regulated by contracts, formal technology-transfer agreements, intellectual property rights or bureaucratic instructions; processes of exploration in which indigenous knowledge was absorbed into European systems of knowledge and intermediaries such as guides, brokers, explorers, and interpreters played a significant role in the process of translation (Gregory, 2000; see chapter by Driver in this volume). Premediated knowledge exchange and knowledge exchange bound by contract have to be distinguished from unintended and discretionary knowledge transfer.

Figure 2.1 shows two diametrically opposed categories of the spatial dissemination of knowledge: Collaborative knowledge sharing between cooperating economic agents in which case the owner of knowledge has an exclusive right to exploit that substantive knowledge for monetary profit and is willing to sell it; and discretionary knowledge dissemination in which case it is not clear from the outset who will be able and willing to absorb and use the publically available knowledge. Collaborative knowledge sharing within organizations or between cooperating units of different social systems and the role of spatial, cognitive, organizational, and institutional proximity (for details see James, Vissers, Larsson, \& Dahlström, 2016; Tsai, 2001; Vissers \& Dankbaar, 2016) are only part of the story. Therefore, research results about collaborative knowledge sharing should not be seen as universally applicable; they represent cases of knowledge transfer that are relatively straightforward and easily described. The most unambiguous and traceable transfers of knowledge are those in which someone has an exclusive right to exploit his or her substantive knowledge ${ }^{2}$ (in this case a private good) for monetary profit (Crevoisier, 2016, pp. 191-192) and is willing to sell it. In such cases "a precise description of the content of knowledge is a prerequisite for its mobility" (Crevoisier, 2016, p. 195), and the use of the knowledge is regulated by contracts, formal technology transfer-agreements, or intellectual property rights. Economic actors will only pay for patents or intellectual property rights if they fully understand the contents of the knowledge and are convinced of its usefulness and value. Discretionary knowledge dissemination is a much more complex communication process. Caught in a crossfire of influences, it seems to be a greater scientific challenge from a geographer's point of view than collaborative knowledge sharing.

Summing up, communication processes of certain categories of knowledge may encounter a lot of impediments, misunderstandings, resistance, contingencies, and

\footnotetext{
2 "From an economic point of view, substantive knowledge is a resource... which is under the control of an actor (generally a firm) who holds exclusivity and can therefore derive income from it" (Crevoisier, 2016, p. 194). "Consequently, rules for the sharing of knowledge become vital to its continued existence and development" (p. 194).
} 


\section{Collaborative Knowledge Sharing}

The owner of the knowledge has an exclusive right to exploit that substantive knowledge for monetary profit and is willing to sell it.

The use of the knowledge is regulated by contracts, formal technology-transfer agreements, intellectual property rights or bureaucratic instructions.
The communication of the knowledge is easy. The owner and buyer of knowledge have a comparable level of prior knowledge and expertise. Economic actors will only pay for patents or intellectual property rights if they fully understand the contents of the knowledge and are convinced of its usefulness and value.

\section{Discretionary Knowledge Dissemination}

The owner or communicator of the knowledge has no exclusive right to exploit that knowledge.
The knowledge is publicly available. Its distribution is not restricted by contracts or regulations. It is not clear from the outset who will absorb and use the knowledge.

The owner or communicator of the knowledge has no influence on how that knowledge is used by others or on the way it is interpreted elsewhere.

The grade of knowledge available for transfer and the absorptive capacities and will of the potential receptors determine the spatial distribution of knowledge.

Knowledge dissemination will fail in many cases, because the potential addressees of information or the users of that knowledge might not have the language skills, expertise, prior knowledge and cognitive capacities necessary to understand, evaluate, and use the available information.

This category of knowledge transfer is difficult to trace.

Fig. 2.1 Two diametrically opposed categories of knowledge transfer (Design by author) 
pitfalls. ${ }^{3}$ In order to avoid misunderstandings and inadequate generalizations, scholars should specify more clearly which categories of knowledge they are talking about and between whom, for which purpose, and under which external conditions the knowledge in question is communicated. So-called low grade, routine knowledge (e.g., the result of a soccer match or the price of a good) can be spread globally in seconds. Other categories of knowledge are place-based or bound to particular contexts; they will remain local or indigenous knowledge and will never (or seldom) be transferred to different (social) environments (for details see Antweiler, 2016; Nüsser \& Baghel, 2016; Senft, 2016; Sillitoe, 2016). Some contents of knowledge will be kept secret as long as possible or necessary. Another group of knowledge categories such as scientific knowledge or specialized professional knowledge will only be understood, applied, accepted, or replicated at a small number of places where experienced and knowledgeable experts or "absorptive capacities" (Cohen \& Levinthal, 1990) are available.

In this chapter I focus on the questions of why the communication process between a source of knowledge and potential receivers of information may fail or be delayed; why the dissemination of high grade knowledge is so selective, and why many agents (social systems) fail in their evaluation of which kind of knowledge might become valuable for them. In the first part, I discuss some of the assumptions and premises that are often leading to narrow conclusions about the mobility of knowledge. In the second section I propose a likely more adequate and more realistic communicator-recipient model that focuses especially on the steps in which the communication process between two agents may fail because part of the information is withheld, not understood, distorted, or rejected as untrue or useless.

\section{Shortcomings and Disputable Assumptions in Research About the Mobility of Knowledge}

\section{Free Access to Knowledge Is Not Equivalent to Acquisition of Knowledge}

A large part of authors doing research on knowledge spin-offs, knowledge spillovers, ${ }^{4}$ knowledge sharing, knowledge flows, or spatial innovation systems focuses predominantly on coordinated, organized, or stipulated knowledge sharing

\footnotetext{
${ }^{3}$ The difficulty of communicating, understanding, and interpreting a text is a main issue of hermeneutics. "Our relation to the speech of others, or to the texts of the past, is not one of mutual respect and interaction. It is a relationship in which we have to fight against misunderstanding..., one in which the focus on communality in language provides but a harmful illusion" (Ramberg \& Gjesdal, 2005/2014, sec. 8, para. 3).

${ }^{4}$ Fershtman and Gandal (2011) distinguish between direct and indirect spillovers. "Direct contributor spillovers exist whenever there are knowledge spillovers between contributors who are directly connected, that is they work together on the same project. (ii) Indirect contributor spill-
} 
within an organization, a community of practice, or an epistemic community; respectively on knowledge exchange among a network of customers and suppliers or between cooperating firms (for an overview of the research see Bathelt, Malmberg, \& Maskell, 2004; Butzin \& Widmaier, 2016; Crevoisier \& Jeannerat, 2009; Crevoisier, 2016; Fershtman \& Gandal, 2011; Fischer, 2001; Fischer, Scherngell, \& Jansenberger, 2006; Foss, Husted, \& Michailova, 2010; Glückler, 2007, 2013; Grabher \& Ibert, 2006; Grabher, Ibert, \& Flohr, 2008; Henderson, 2007; Huber, 2012; Jaffe, Trajtenberg, \& Henderson, 1993; James, Vissers, Larsson, \& Dahlström, 2016; Jeannerat \& Crevoisier, 2016; Malmberg \& Maskell, 2002; Oinas \& Malecki, 2002; Scherngell, 2007; Vissers \& Dankbaar, 2016).

Within a thick network "which is supported by close social interactions and by institutions building trust and encouraging informal relations among actors" (Huber, 2012, p. 110; see also Breschi \& Malerba, 2001, pp. 819-820) and within an epistemic community whose members command a comparable level of prior knowledge and expertise, communication of knowledge and local learning processes seem to be comparatively unproblematic.

It is a popular idea that firms located in clusters benefit from local knowledge spillovers: knowledge created by a local agent can be accessed and used by other agents without market interaction and financial compensation for the producer of the knowledge. (Huber, 2012, p. 108)

The basic idea of knowledge spin-offs or spillover is "that the creation of new knowledge by one firm has positive external effects on the knowledge production activities of other firms, either because knowledge cannot be kept secret, or because patents do not guarantee full protection from imitation" (Karlsson \& Manduchi, 2001, p. 110). Fischer (2001) speaks of knowledge spillovers when "knowledge created by one firm can be used by another without compensation or with compensation less than the value of the knowledge" (p. 204). In the last couple of years, an increasing number of authors found that "in an innovative technology cluster local knowledge spillovers and territorial learning might not be as widespread as the literature tends to suggest" (Huber, 2012, p. 114; see also the critiques of Breschi \& Lissoni, 2001a, b; Breschi \& Malerba, 2001; Foss et al., 2010; Karlsson \& Manduchi, 2001). Communication and dissemination of particular scientific or technical knowledge will only be successful when the source of knowledge and the recipient of information have a comparable level of prior knowledge and expertise, when they speak a common language, ${ }^{5}$ and share common goals, interests, and "thought styles" (in the sense of Fleck, 1935/1979, pp. 99, 142; see also Trenn \& Merton, 1979, p. 159). In reality, agents and firms differ greatly in their knowledge and expertise, their ability to learn, their competence to interpret signs and data, and their inventiveness.

overs exist whenever there are knowledge spillovers between contributors who are not directly connected" (p. 77).

${ }^{5}$ According to Gadamer, "human being...is a being in language. It is through language that the world is opened up for us. We learn to know the world by learning to master a language" (as paraphrased in Ramberg \& Gjesdal, 2005/2014, sec. 5, para. 3). 
The assumption that new and valuable knowledge will be taken up with benevolence or great enthusiasm is naïve. Even within the same epistemic community, new knowledge is not disseminated inherently; it may be criticized, rejected, or just ignored. Studies on the history of science offer many examples showing that it may take years or decades for path-breaking new paradigms and seminal new research results to be taken up by other scholars of the same research field, let alone those of neighboring disciplines. An easy access to globally available scientific publications is not at all tantamount to the mobility of the knowledge presented in those publications. This refers not only to the humanities and social sciences, sometimes called "fragmented adhocracies" (Whitley, 1984a, p. 776; Whitley, 1984b, p. 34; see also Froese \& Mevissen, 2016, pp. 35-37) that tend "to produce rather diffuse and broad contributions to general intellectual problems which are subject to contrasting interpretations and evaluations" (Whitley, 1984b, p. 36), but also to the hard sciences. The so-called Semmelweis reflex - a metaphor for the reflex-like tendency to reject new theories, new methods, new research questions or new knowledge because they contradict dominant paradigms, established norms or beliefs-is also widespread in the sciences. ${ }^{6}$

Research on the mobility of knowledge should focus more on the complexity of communication processes. Scholars should ask why pathbreaking new research results or technical inventions may be ignored, contested, and declined for long periods of time in spite of their great medical, technical, or economic usefulness. They should also pay more attention to the fact that in a competitive world there are many situations in which agents and organizations need to acquire external knowledge that is not voluntarily offered or shared by others. In such cases, agents need

\footnotetext{
${ }^{6} \mathrm{~A}$ number of famous scientists had the impression of coming up against a brick wall when they first published their outstanding scientific results. It took more than 30 years for the significance of Gregor Mendel's (1822-1884) genetics to be recognized. The pathbreaking findings of Ignaz Semmelweis (1818-1865) about childbed fever (published in 1847 and 1848) were repudiated by professors of medicine until the late 1860s. Alfred Wegener's (1880-1930) theory of continental drift (1912) continued to be attacked by his colleagues until the early 1960s. Even Nobel Prize winners had to wait for many years until their research gained the recognition of their colleagues. Physiologist Albrecht Kossel (1863-1927) was one of three Heidelberg physiologists who established biochemistry as a key subject of the life sciences. Kossel was awarded the Nobel Prize in Medicine in 1910 for his contributions to knowledge about the "chemistry of the cell nucleus". His research laid the foundation for biochemistry and molecular biology and was unique in its effect on the development of the life sciences. Efforts to make biochemistry an independent discipline at Heidelberg University were continually interrupted not only by outside circumstances (World War I and II) but also by dissent from the professors inside the fields of chemistry and medicine. It was not until 1961 that the first full professor of physiological chemistry was appointed at Heidelberg university (Schafmeier, Franke-Schaub, Schirmer, \& Brunner, 2012, p. 223). Harald zur Hausen (born 1936), Heidelberg's Nobel Prize winner in medicine in 2008 (for details see Mager, 2012) started his seminal research about human papillomavirus 6 in 1972. In 1976, he published the hypothesis that human papillomavirus plays an important role in the cause of cervical cancer. His work on papillomaviruses and cervical cancer received a great deal of scientific criticism, and sparked a major scientific controversy with other scientists favoring herpes simplex as a cause for cervical cancer. It took some 10 years for zur Hausen's research results to become widely accepted by his colleagues (https://en.wikipedia.org/wiki/Harald_zur_Hausen).
} 
the cognitive capacity and experience to interpret data, signs, and patterns; to anticipate grassroots developments; to draw conclusions from incomplete information; to disclose secrets; to evaluate the potential of new ideas; to foresee new markets; to invent new techniques; and to explore unknown grounds by crossing disciplinary borders.

\section{The Impact of New Information and Communication Technologies on the Mobility of Knowledge}

Some of the problematic assumptions about the mobility of knowledge can be traced back to the opinion that the social and economic impacts of new communication technologies are clear and unambiguous, that various means of telecommunication will substantially reduce the amount of face-to-face contacts and therefore diminish the role of centers. This misjudgment has a long history. At the end of nineteenth century, the Bell Company advertised the telephone with the argument that it would decrease the need for business travel because many discussions, negotiations, and decisions would no longer need face-to-face contacts. It was expected that power and decision making could be more decentralized and cities would lose part of their location advantages. However, the Bell Company was one of the first to centralize its decision making after introducing the phone. ${ }^{7}$

Similar forecasts were made after the introduction of the Internet and other electronic communication. Some observers (Cairncross, 1997; Knoke, 1996; Naisbitt, 1982; Negroponte, 1995; Relph, 1976; Toffler, 1980) went as far as to predict that advances in electronic communication would lead to an almost unbounded mobility of knowledge. Anyone using the Internet would have access to the knowledge he or she needed. Others criticized this theoretical position as early as the 1970s and 1980s (Short, Williams, \& Christie, 1976; Meusburger, 1980, pp. 105-107). They argued that new information technologies would primarily facilitate access to freely offered, easily understandable information but not replace the need for face-to-face contacts among high-level decisions makers. Almost any proliferation of new communication devices increased the division of labor, promoted further differentiation of complex social systems, and made some aspects of face-to-face contacts dispensable-although it simultaneously created a large new demand for them.

Many new means of communication (script, paper, printing machine, telephone, Internet, and so on) benefited in the first phase of their dissemination primarily those in power and created new inequalities concerning the access to knowledge (see chapter by Bloor in this book). New telecommunication technologies also contributed to the spatial bifurcation of skills; to a further spatial concentration of workplaces affiliated with high-level decision making in regional, national, and global

${ }^{7}$ Personal information of Jean Gottmann (Oxford) in March 1977. 
centers $^{8}$; and to a decentralization of routine activities in low-cost peripheries (Meusburger, 1980, 1998, 2000, 2008; Meusburger, Koch, \& Christmann, 2011).

It is true that communication devices improved access to information; they changed the structure, size, and complexity of organizations and the ways in which social systems and networks were coordinated and governed in space. But none of these inventions ever abolished the spatial concentration of power or central-peripheral disparities pertaining to the production, dissemination, and use of high-level knowledge. On the contrary, the knowledge gap between better and less educated segments of society (Tichenor, Donohue, \& Olien, 1970) and the research gap between the global centers and peripheries increased. Studies about the spatial distribution of Nobel Prize winners (Mager, 2012) or about worldwide scientific collaborations of research centers (see Raditsch, 2012, p. 289; Seltmann, 2012, p. 284) belong to the most convincing evidence for the selectivity of knowledge exchange.

When it comes to the mobility of high-grade knowledge, some authors seem to focus too much on the technically imaginable and to overlook relations between power and knowledge; asymmetric power relations between top and base or center and periphery of a social system; and spatial disparities of literacy, educational achievement, and international reputation of research. They underestimate emotional and psychological aspects of communication, the role of mutual trust, the symbolic meaning of places, and the importance of nonverbal communication. What is possible from a technical point of view (e.g., decentralization of decision making in social systems) may not be feasible because of human preferences and psychological processes.

When asking in which situations communication technologies may replace faceto-face contacts, it is necessary to distinguish between different categories of contacts, for example, between orientation contacts, planning contacts, and routine contacts; between internal (within the social system) and external contacts (with other social systems); and between face-to-face contacts and indirect contacts (via letter, phone, email, etc.). This was already being emphasized in the 1970s and early 1980s by Goddard (1971), Goddard and Morris (1976), Goddard and Pye (1977), and others. However, most of these categorical distinctions seem to be neglected nowadays.

The importance of face-to-face contacts and the possibility of replacing them with indirect contacts (e.g., letters, phone, emails) depend on the type and grade of knowledge (information) that has to be transferred from $\mathrm{A}$ to $\mathrm{B}$, on the relations between the persons communicating with each other (cooperation or competition, trust or distrust, friend or stranger), on the degree of uncertainty a person or social system is exposed to in the external environment, and on many other issues discussed in organization theory and human geography (for details see Bathelt \& Glückler, 2011; Goddard, 1971; Goddard \& Morris, 1976; Goddard \& Pye, 1977; Mintzberg, 1979; Storper \& Venables, 2004).

\footnotetext{
${ }^{8}$ The term center is not defined in a topographic sense but from the viewpoint of organization theory. A center is the place where the highest authority of a social system is located (Gottmann, 1980; Strassoldo, 1980).
} 
There is no doubt that digital information systems provide new opportunities for the internal sharing and joint utilization of voluntarily offered, easily understandable information, especially within organizations or supply chains, between a headquarters and its spatially dispersed production and customer bases. Communication partners who trust each other and have a long history of successful cooperation will exchange most of their routine information by indirect contacts. However, indirect contacts are seldom used when the degree of uncertainty and risk is high and the degree of mutual trust still low; when communication has to be kept secret; or when hazardous cooperation has to be cautiously prepared. Motivation, mutual trust, and persuasion $^{9}$ are easier achieved by face-to-face contacts than by letters or other forms of indirect communication.

A large part of information needed for crucial decision making in risky situations is not stored in databases and not shared via phone or email but is predominantly acquired via face-to-face contacts between highly experienced experts and top decision-makers of different organizations. In such situations nonverbal communication, careful observation of facial expressions of conversational partners, and interpretation of signs and patterns in the environment become very important. However, by the time agents or units of different social systems have come to trust each other and are cooperating well, or the processes of research, design, and production are ready to be formalized and standardized, many face-to-face contacts have become routine and replaceable with electronic communication.

\section{Is Codified Knowledge a Public Good and a Tradable Commodity? The Necessity to Distinguish Between Knowledge and Information}

For many years, economists regarded codified knowledge as a public good and a tradable commodity. This premise is almost inalienable to neoclassical economic theory, but highly questionable. Knowledge is only a public good-in the economic sense - if it can be used without additional costs. Knowledge is only tradable if possible recipients are able to understand and use the offered information. "[A]chieving understanding is the initial step in a transfer process that ends when the recipient is able to use the shared knowledge in his or her area of expertise or domain" (Tortoriello, Reagans, \& McEvily, 2012, pp. 1025-1026). Scholars supporting the assumption that knowledge is a tradable commodity should not forget to mention the number of persons who are able to take advantage of a particular kind of knowledge. It makes a difference whether a scientific publication is understood by 100 , 10,000 , or 500 million people and whether these persons are randomly distributed in space or concentrated in a few places (e.g., research laboratories).

\footnotetext{
${ }^{9}$ For details about successful persuasion see Cialdini (2008).
} 
The premise that codified knowledge is a public good and a tradable commodity is justified by two arguments. Some economists argue that new knowledge cannot be kept secret and becomes public in the long term. However, this argument overlooks the fact that in highly competitive situations, success or failure in achieving a certain goal does not depend on knowledge or information per se but on a short lead in knowledge, on receiving information, acquiring skills, or installing new technologies earlier than competitors. ${ }^{10}$ In most cases it is the earlier availability of specialized, unique, or rare knowledge that makes one social system, institution, or region more successful than the other (for details see Liebeskind, 1996, p. 98; Meusburger, 2013, p. 37).

The second argument used by economists to defend their premise is that knowledge and information are more or less the same, that a large part of knowledge can be codified, and that codified knowledge can almost completely be transformed into information easily transferable to other agents (a detailed discussion is provided by Ancori, Bureth, \& Cohendet, 2000, p. 256; Cowan, David, \& Foray, 2000, p. 221; Spinner, 1994). Ancori et al. (2000) explained why the codification of knowledge is a major concern of economists and why they find it difficult to give up their claim that there is (almost) no difference between codified knowledge and information. To be treated as an economic good with discernible and measurable characteristics, knowledge must be put into a form that can be exchanged, and that form is information. This view has been challenged not only by work in sociology of science (Callon et al., 1999; Collins, 1983), geography of knowledge (Livingstone, 1995, 2000, 2002, 2003; Meusburger, 1998, 2008), philosophy (Abel, 2004; Gadamer, 1960/1999), and communication theory but also by some economists (Amin \& Cohendet, 2004; Ancori et al., 2000). Cohendet and Steinmüller (2001) present a number of arguments why a clear distinction between knowledge and information is indispensable.

The fact that codified knowledge is made public or available for free does not mean that it is understood, accepted, or used by all those who have access to the information and could profit from it. The quality and accuracy of codifying knowledge or the accessibility of information is only one side of the coin. The other side concerns the cognitive abilities, goals, interests, motivation, attention, emotions, ideology, and prejudices of the (potential) recipients of information and the milieus they are embedded in. ${ }^{11}$ It should not be taken for granted that all the potential receivers have the cognitive capacity and willingness to use the available information to their benefit. If information is published in Chinese characters, Gujarati, or cuneiform script, billions of people having access to this information via the Internet

\footnotetext{
${ }^{10}$ In the financial system or the stock market an information lead or delay of seconds or minutes may decide whether people earn or lose money; for news agencies a lead of $1 \mathrm{~h}$ may be decisive; for scientists, days or weeks may determine whether their publication is regarded as pioneering work or not.

${ }^{11}$ The importance of knowledge milieus or discipline-specific contexts for knowledge transfers and research is discussed by Fleck (1935/1979), Froese and Mevissen (2016), Matthiesen (2009, 2013), Meusburger (2009a, 2015b), and others.
} 
For Lorentzian (2+1)-gravity with vanishing cosmological constant, each element $\lambda \epsilon$ $\pi_{1}(M)$ is associated with two canonical Wilson loop observables which are the fundamental physical observables of the theory. It is shown in $[16,17]$ that they generate via the Poisson bracket the two fundamental transformations that change the geometry of the (2+1)-spacetime, grafting and earthquake performed simultaneously on all surfaces of constant cosmological time. These canonical Wilson loop observables, in the following referred to as 'mass' $m_{\lambda}$ and 'spin' $s_{\lambda}$ of $\lambda \in \pi_{1}(M)$, are obtained by applying the functions $m, s: I S O_{0}^{+}(2,1) \rightarrow \mathbb{R}$

$$
m:\left(\mathrm{e}^{n^{b} J_{b}}, \boldsymbol{a}\right) \mapsto|\boldsymbol{n}|, \quad s:\left(\mathrm{e}^{n^{b} J_{b}}, \boldsymbol{a}\right) \mapsto \boldsymbol{a} \cdot \hat{\boldsymbol{n}},
$$

to the holonomy along $\lambda$. Note that they are closely related to the traces of the Poincaré-valued holonomies. Using the $\mathfrak{s u}(1,1)$ representation $(2.4)$ one finds

$$
\begin{aligned}
& \operatorname{Tr}\left(\mathrm{e}^{n^{b} J_{b}}\right)=2 \cosh \left(\frac{1}{2} m\left(\mathrm{e}^{n^{b} J_{b}}, \boldsymbol{a}\right)\right), \\
& \operatorname{Tr}\left(\mathrm{e}^{n^{b} J_{b}} \cdot a^{c} J_{c}\right)=\sinh \left(\frac{1}{2} m\left(\mathrm{e}^{n^{b} J_{b}}, \boldsymbol{a}\right)\right) \cdot s\left(\mathrm{e}^{n^{b} J_{b}}, \boldsymbol{a}\right) .
\end{aligned}
$$

It has been shown that the mass and spin observables associated with all elements of the fundamental group $\pi_{1}\left(S_{g}\right) \cong \Gamma$ form a complete set of observables. Their values determine the spacetime uniquely and they parametrize the physical phase space (2.27) of the theory.

Fig. 2.2 The ability to read an information does not mean to understand it (Source of the text: Meusburger, C., 2009, p. 11)

will not be able to read it. A certain type or content of knowledge may be perfectly codified in equations, published in international journals, and well understood by 50 to 100 theoretical physicists, but the rest of the world population may just not have acquired the prior knowledge ${ }^{12}$ necessary to read and understand the mathematical equations and to integrate this new information in their own knowledge base.

This discrepancy between knowledge and information can be demonstrated by Fig. 2.2. This paragraph is taken from a paper published in an important international journal available on the Internet, where billions of people have access to it. It uses two codes - the English language and mathematical formulas. English is the most widespread language in the world, and although the mathematical formulas may be understood by less people, they can be learned in a reasonable amount of time. However, the mastery of these two codes does not mean that readers will be able to understand the message presented in this information and to integrate it into their knowledge base. They can only understand the offered information if they have studied and gathered research experience in special fields of theoretical physics. One needs prior knowledge to understand the information offered in Fig. 2.2.

From the viewpoint of the producer (source) of new knowledge, the boundary between information and knowledge might become blurred. With regard to the recipient of a message, the difference between knowledge and information becomes quite distinct. As soon as the communication process occurs between two individu-

\footnotetext{
${ }^{12}$ The term Vorwissen (here translated as prior knowledge) draws on Gadamer's (1960/1999) term Vorverständnis (prior understanding).
} 
als, the distinction between knowledge and information becomes indispensable. Receiving information is in many cases not equivalent with gaining knowledge. The higher the grade of knowledge, the clearer the discrepancy between knowledge and information becomes from the viewpoint of the receivers of information. Making information available is not tantamount to disseminating knowledge. A scientific publication may be available worldwide and free of charge, but the proportion of the population being able to understand the semantic meaning of the information may be less than one per million. Knowledge does not move from A to B if people at place $\mathrm{B}$ do not understand the information offered to them.

Therefore, I question the assumption shared by Fujita, Krugman, and Venables (1999), Maskell and Malmberg (1999), and many others that the more codified or the more public the knowledge involved, the more mobile it is and that knowledge, once codified, is almost instantly available to all firms at zero cost regardless of their location. Their assumption is only valid for easily understandable information that has little value in economic competition.

\section{Nominal and Ordinal Differentiations of Knowledge}

Metaphors such as knowledge spillovers or knowledge flows are misleading for various reasons. They suggest that codified knowledge or information disseminate like a liquid once they are no longer secret. Liquids spilling out of a bowl or flowing on a plain affect first the proximate and finally the distant agents. Most categories of knowledge do not follow a linear diffusion model as the liquid metaphor suggests.

In order to avoid misunderstandings, studies on the mobility of knowledge should always specify which categories of knowledge are being addressed. Knowledge embodied in people has to be distinguished from knowledge presented in publications and knowledge integrated in machines. Knowledge sharing within organizations or between cooperating units should be distinguished from knowledge acquisition in a risky and competitive external environment. Codified routine knowledge storable in databases has to be distinguished from intuition, foresight, and competence based on years of experience and learning. Knowledge exchange between experts in the same domain (e.g., between the owner and user of a patent or between two molecular biologists doing research about the same topic) has to be discerned from communication between expert and layperson.

Most categorizations of knowledge used so far-for example, the distinctions between codified and tacit knowledge; explicit and implicit knowledge; analytical, synthetic, and symbolic knowledge (Asheim, 2007); factual knowledge ${ }^{13}$ and orien-

\footnotetext{
${ }^{13}$ Factual knowledge is needed in order to analyze a situation as precisely as possible and to offer solutions to technical or scientific problems. Depending on the task to be solved, it may consist of scientific knowledge, domain-specific expertise, professional skills, familiarity with codes (foreign languages, mathematical equations) and theoretical concepts, or various cognitive abilities, such as the skills of perceiving problems earlier than others or evaluating situations in a more realistic way
} 
tation knowledge ${ }^{14}$ (Meusburger, 2015a); or between substantive and significant knowledge (Crevoisier, 2016) - are nominal distinctions. Some of these distinctions - those between codified and tacit or implicit ${ }^{15}$ and explicit knowledge-are quite problematic. What is implicit knowledge for one person or at one point in time can be perfectly explicit for another person or at some other time. It is not possible to draw a generally valid line between tacit and codified knowledge. Some authors view codified and tacit knowledge as essentially complementary because all forms of codified knowledge require tacit knowledge to be useful (Ancori et al., 2000, p. 257). Knowledge may remain tacit just because the source and recipient have no skills of how to codify a specific sort of knowledge (Ancori et al., 2000, pp. 273-274; Baumard, 1999; Collins, 2001).

In spite of the fact that the concept of tacit knowledge is widely discussed (see Ancori et al., 2000; Baumard, 1999; Collins, 2001; Cowan et al., 2000; Gertler, 2003; Lam, 2000; Polanyi, 1967; Reber, 1993), "the terminology and meaning of 'tacitness' in the economics literature [have] drifted far from its original epistemological and psychological moorings [and have] become unproductively amorphous" (Cowan et al., 2000, p. 213). Some authors use the concept of tacit knowledge as a kind of umbrella term for nonverbal knowledge that cannot be articulated by using linguistic expressions (e.g., the competence to play violin or to ski) and nonpropositional knowledge (e.g., knowing how to understand a bodily movement). ${ }^{16}$ In summary, "The concept... of knowledge tacitness has been stretched too far for being still useful" (Breschi \& Lissoni, 2001b, p. 262).

In addition to nominal categorizations of knowledge, ordinal categorizations of knowledge ${ }^{17}$ focusing on different grades of knowledge are needed as well. It has already been mentioned that certain types of information can only be read and

than others. Factual knowledge searches for and relies on a kind of truth that can be empirically tested and rejected.

${ }^{14}$ Orientation knowledge provides a point of moral reference; it declares what is good or evil, right and wrong. It may consist of, for example, religious and ideological convictions, prejudices and stereotypes, national myths, political legends, loyalty to a community, or cultural traditions. Orientation knowledge creates collective memories and sustains the internal cohesion and motivation of a social system; it mobilizes loyalty.

With regard to the individual actor, it is evident that there is no clear boundary between factual and orientation knowledge. Both knowledge systems intermingle with each other. However, on the level of large and complex organizations, a clear functional differentiation between factual knowledge and orientation knowledge can be observed. Experts of factual knowledge have other tasks, need different training and skills, and use other methods than experts of orientation knowledge do (for details see Meusburger, 2015a).

${ }^{15}$ According to the philosopher Abel (2004), "tacit knowledge means those aspects of knowing that are implicit in situations of perceiving, speaking, thinking and acting, but are not made explicit, are not disclosed at surface" (p. 322).

${ }^{16}$ A number of authors argue, ironically, that the meaning and functioning of tacit knowledge usually remains tacit (Martin \& Sunley, 2003, p. 17; Huber, 2012, p. 109).

${ }^{17}$ Another example of an ordinal categorization of knowledge has been presented by Willke (1998, p. 172) who discriminated between "simple knowledge" (observations of first order) and "reflexive knowledge" (observations of second order). 
understood by people having a certain degree of prior knowledge at their disposal. The acquisition of this prior knowledge may take days, months, or many years and is associated with costs. ${ }^{18}$ Prior knowledge may refer to learning a foreign language, graduating in a scientific discipline, doing research about a specific topic for many years, gaining experience in a profession or community of practice for more than 10 years, improving one's cognitive skills and creativity, or just become literate.

It is possible to categorize knowledge in an ordinal scale according to the cognitive capacities, efforts, time, and costs needed to acquire it. High grades of knowledge demanding well-developed cognitive skills, years of study, research, professional training, and experience to be understood by the recipients of the information have to be distinguished from lower grades of knowledge, requiring much less educational achievement, less professional skills, and less experience to be understood, and from everyday routine knowledge easily understood by almost anybody. Such an ordinal differentiation of knowledge seems to be indispensable when it comes to the spatial dissemination of various categories of knowledge.

\section{An Attempt to Construct a More Realistic Communication Model}

When studying the communication and spatial dissemination of different categories of knowledge it is first necessary to consider both the cognitive processes of a communicator and potential recipients of information and the intervening obstacles and learning loops within the communication process. In this chapter, the emphasis is on microprocesses of communication, on factors that influence the knowledge transfer between individuals, such as the role of cognitive skills, competencies, interests, needs, motivation, beliefs, and ideologies. This micro scale of communication is the basis for communication links on the macro scale, for example, between institutions. As Foss et al. (2010) have pointed out,

macro-macro links are, methodologically speaking, shorthand for a more complex substructure of individual action and interaction. For example, organizational structure never directly impacts organizational performance; it may well effect, but only indirectly, namely through influencing individual conditions, actions and interactions. (p. 464)

In order to reduce the complexity of the communication process between person $\mathrm{X}$ in place $\mathrm{A}$ and person $\mathrm{Y}$ in place $\mathrm{B}$, I propose a model focusing on some of the factors crucial to the process of knowledge exchange between communicator and recipient that can interrupt, distort, delay, modify, or stop it. They include at a minimum

- the willingness of person $\mathrm{X}$ to share his or her knowledge with others,

- the ability of person $\mathrm{X}$ to verbalize and codify his or her knowledge,

\footnotetext{
${ }^{18}$ Among others, Foss et al. (2010) mentioned "that costs of sharing and integrating knowledge differ as a function of the characteristics of knowledge" (p. 468).
} 
- the degree of attention, reputation, and visibility of the platform where the information is first or predominantly presented,

- the code in which an information is written,

- the communication channel (and type of contact) used to transmit the information,

- the place- or context-dependent chances of recipient $\mathrm{Y}$ to receive the information in time,

- the ability of recipient Y to read the used code,

- the prior knowledge ${ }^{19}$ or cognitive and absorptive capacities needed by $\mathrm{Y}$ to understand the information and integrate it into his or her knowledge base (rulebased processing of information, reflective system), ${ }^{20}$

- the willingness (motivation) of the recipient to accept the new information (associative processing of information, impulsive system), and

- the pressure and control of the social environment, knowledge milieu, and culture the recipient of an information is exposed to. ${ }^{21}$

Each stage of the communication process has a high degree of actor-, community-, and place-dependent contingency and can act like a filter, ${ }^{22}$ letting some information pass in its original meaning and withholding, transforming, or distorting other information. In this context, the term filter is used as a metaphor for various cognitive processes, mind-sets, thought-styles, ${ }^{23}$ and power relations that influence

\footnotetext{
${ }^{19}$ Prior knowledge is not something people possess; it is something they constantly develop in a way similar to the knowledge spiral described by Nonaka and Takeuchi (1995, p. 71). Such learning processes may encompass personal experience, professional training, graduation in a scientific discipline, or encultured knowledge (Blackler, 2002) arising from socialization and acculturation in specific cultural settings or shaped by stable relationships in organizational routines and interpersonal relationships. Prior knowledge also includes latent subconscious experience and intuition.

${ }^{20}$ In recent years many social and cognitive psychologists have proposed that social behavior is controlled by two interacting systems - the reflective and the impulsive system-that follow different operating principles (for an overview of the literature see Krishna \& Strack, 2017; Smith \& DeCoster, 2000; Strack \& Deutsch, 2004, 2007). "The reflective system generates behavioral decisions that are based on knowledge about facts and values, whereas the impulsive system elicits behavior through associative links and motivational orientations" (Strack \& Deutsch, 2004, p. 220).

${ }^{21}$ It goes without saying that both the communicator and recipient of information are embedded in and influenced by contexts and spatial relations that affect the generation and diffusion of knowledge. However, this topic has already been discussed elsewhere (Meusburger, 2008, 2009a, 2013, $2015 \mathrm{a}, \mathrm{b})$ and will not be repeated here.

${ }^{22}$ The concept of filter has already been used by Fiedler and Wänke (2009), Shera (1970) and Wagner and Sternberg (1987). "Knowledge... is the consequence of a filtering process; the process of filtering...facts through the ethical system or the intellectual system, or the system of scholarship... of the individual who receives it" (Shera, 1970, p. 96). In a similar way, Meusburger (1998) and Andrews and Delahaye (2000) examine the influence of the psychological filter on knowledge processes. Psychological determinants of individual engagement in knowledge sharing are also examined by Osterloh and Frey (2000).

${ }^{23}$ Fleck (1935/1979) defines "thought style as the readiness for directed perception and appropriate assimilation of what has been perceived" (p. 142). In a more detailed definition he describes
} 
the selectivity and direction of the perception, processing, evaluation, and interpretation of incoming information and the enactment of knowledge into practice. At each step of the communication process, selective perception, loss of information, misunderstandings, distortions, and misrepresentations are possible. The effects of these filters and other cultural, social, and psychological factors and processes are the most important reason why certain grades and contents of knowledge circulate only between particular people and places and bypass others, why the dispersion of particular research results is delayed for many years, and why certain categories of knowledge travel at different speeds and very selectively in the spatial dimension.

Any visualized model runs the risk of being misunderstood as a description of static relations and mechanistic interactions. In reality, these processes and steps of communication are not arranged sequentially as depicted in Fig. 2.3. They must be conceived of as interactive learning loops that incorporate cognitive skills, intellectual capacities, interests, motives, and prejudice of agents; organizational structures, strategic visions, resources, and work practices of social systems (institutions); and cultural influences, power relations, and spatial contexts.

The first step in the communication process is clarifying whether and to what extent a producer (communicator) of new knowledge is willing to share his or her knowledge. Andrews and Delahaye (2000); Cabrera, Collins, and Salgado (2006); and others identified various psychological, organizational, and system-related determinants of individual engagement in knowledge sharing. Scholars and other holders of valuable knowledge "actively make decisions about what knowledge they would share with whom, when" (Andrews \& Delahaye, 2000, p. 803). In many situations, it may be wise or an advantage to leave competitors or opponents uncertain about one's knowledge and goals. A new bargain is normally made public only after it has been signed. Particular scientific results may be shared only if scholars trust their colleagues or after the research results have been published or patented. Scholars, inventors, journalists, and other agents want to retain the ownership of their ideas. In the interviews conducted by Andrews and Delahaye (2000), "scientists spoke of the enormous personal impact of sharing knowledge unwisely: they could be swallowed up, cut out of the chain, and risked losing credit, visibility, first authorship, and a place on the patent" (p. 803).

The act of keeping knowledge secret, or restricting access to it, has a long tradition in human history because it provides the owner of secret knowledge competitive advantages or privileges. Many religions had their holy or secret knowledge that priests or shamans passed on only to chosen successors; some religions had temple precincts and sanctums that only priests were allowed to enter. In modern

\footnotetext{
"thought style as [the readiness for] directed perception, with corresponding mental and objective assimilation of what has been so perceived. It is characterized by common features in the problems of interest to a thought collective, by the judgment which the thought collective considers evident, and by the methods which it applies as a means of cognition. The thought style may also be accompanied by a technical and literary style characteristic of the given system of knowledge" (Fleck, 1935/1979, p. 99).
} 


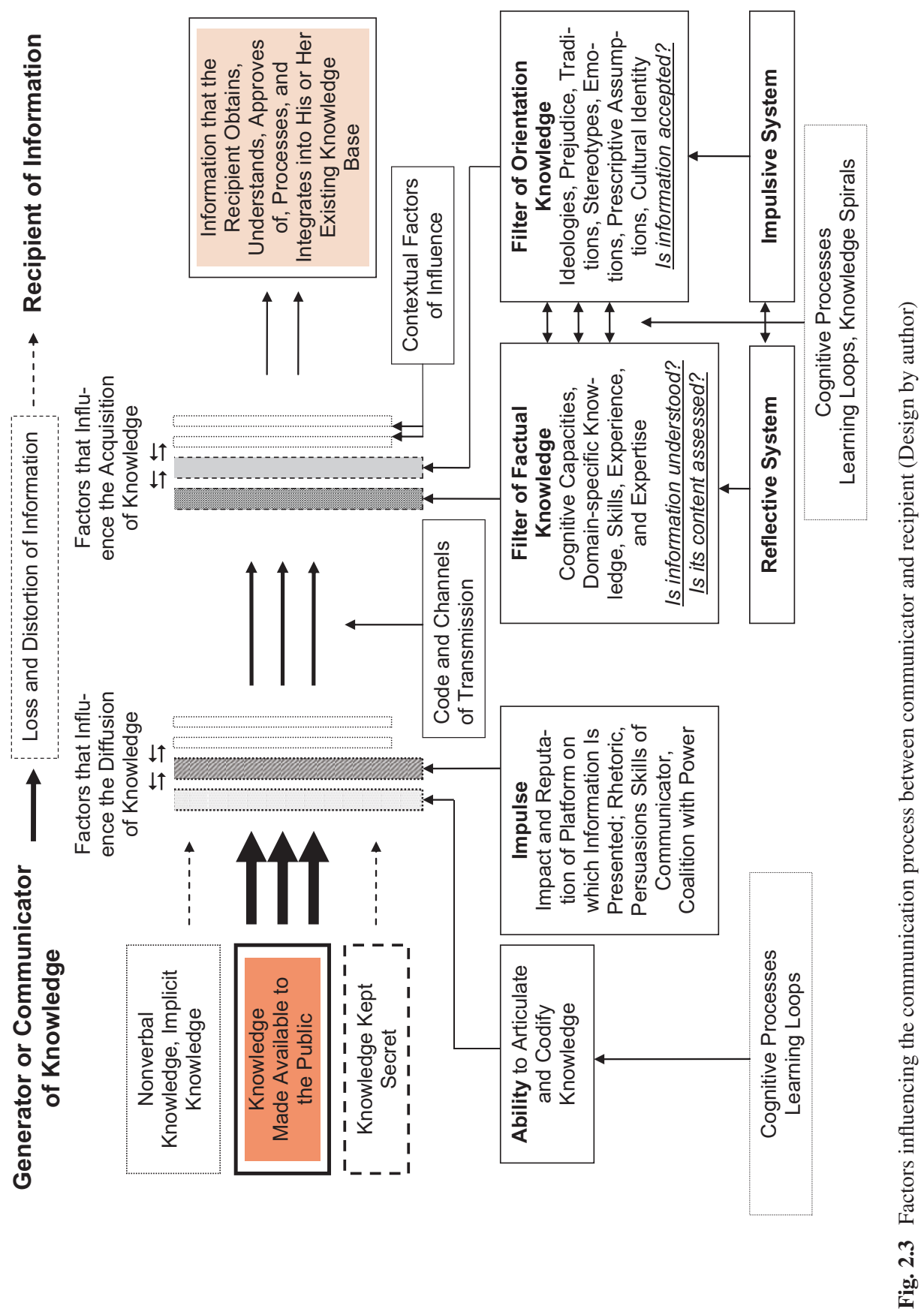


society, billions of dollars are spent to conduct or prevent industrial or military espionage.

The second question affecting the communication process is whether and to what extent a producer of new knowledge is able to articulate that knowledge in language, signs, and gestures; to codify it; to transform it into physical objects (e.g., scientific instruments, machines); or to demonstrate and teach his or her superior competence in other ways. It is common knowledge that a person knows more than he or she is able to articulate to someone else.

No matter how a given case may be described, the description is always a simplification permeated with apodictic and graphic elements. Every communication and, indeed, all nomenclature tends to make any item of knowledge more exoteric and popular. Otherwise each word would require a footnote to assign limitations and provide explanations. Each word of the footnote would need in turn a second word pyramid. (Fleck, 1935/1979, p. 114)

The third issue concerns the code in which new information is transformed. Different producers of knowledge are proficient in or prefer different codes. Some codes are understood by a large number of people; others, by only a few. A manuscript published in Estonian has fewer potential readers than a publication in English. The learning of a code may be costly and time consuming. Knowing a code "will discriminate between those who can grasp the meaning of the messages, and those who cannot (or at least have to sink in very high costs to learn...the codebook)" (Breschi \& Lissoni, 2001b, p. 262).

The fourth factor that can enhance or confine dispersion of knowledge concerns the platforms on which (new) knowledge is presented. Experts, scientists, professionals, and other sources of knowledge require a platform of attention that effectively puts them in the spotlight and promotes their results and ideas in the relevant media. Different platforms achieve impulses of varying strength; they have dissimilar reputations, credibility, visibility, and audibility and therefore attract unequal attention. Because people's memory and information-processing capacities are limited, their attention is selective and a scarce resource (Franck, 1998). Selectivity in perception determines what is learned and kept in memory and what is excluded. Judgment of significance is neither impartial nor spatially invariant. Considering today's flood of information, the contents of a message or its usefulness for society are often less important for its wide diffusion than the platform on which it is presented. Manipulating the access to platforms of varying importance is an effective instrument of executing power.

The fifth factor concerns the channel or medium (TV news, scientific journal, book, lecture at university, Internet) through which new information is made public. Different media of transmission reach different audiences and have unequal ranges of coverage. In authoritarian states most of the media channels are controlled by institutions of political power; therefore, specific messages will not be distributed.

The next three steps of the communication process concern the potential recipients of information. Most studies on knowledge transfer overemphasize the provider and codifier of knowledge and assume that potential recipients will understand, accept, and use the knowledge available to them. In reality, the sources and trans- 
mitters of knowledge have limited influence on the extent to which their knowledge is accepted and processed or on the way it is interpreted elsewhere.

The first question is whether a recipient has the resources or technical devices to receive the new information in time and to communicate with others. Millions of people have no access to the Internet, and even more will never have a chance to use a university library or access e-journals. If the resources to receive a message are available, the next question is whether the recipient is able to read the code in which it is written. At the beginning of the twenty-first century some 900 million people were illiterate. Most western scholars are not proficient in Chinese, Arabic, or Hebrew letters. Some are quite helpless when it comes to mathematical or chemical formula. In science and the humanities, language barriers are among the most severe impediments for the exchange of knowledge (for details see Paasi, 2015). ${ }^{24}$

A recipient may indeed be able to read incoming knowledge, but it nonetheless has to pass at least three more filters before it has been successfully processed and incorporated into that person's existing knowledge base. The first is the recipient's level of factual knowledge, the second his or her decision about the usefulness or relevance of the new information, and the third his or her orientation knowledge.

Even after a recipient has received knowledge from an external source, he must still figure out how to use it. The recipient must appraise, adapt, and ultimately "transform" whatever he has learned from the source in order for it to be useful in his work context. (Tortoriello et al., 2012, p. 1026)

The filter of factual knowledge decides whether a person is able to understand the semantic meaning of the incoming information, to evaluate its importance and shortcomings, to recognize its usefulness and far-reaching implications for his or her needs and goals, to integrate it into his or her knowledge base, and to transform the knowledge into action. The evaluation of the usefulness of knowledge is a function of prior knowledge, but is also influenced by context- and discipline-specific factors (for details see Froese \& Mevissen, 2016). Experts in different domains, with different levels of expertise and different strategic interests, may evaluate new incoming information disparately. Persons who have not completed years of study and research in molecular biology or theoretical physics have little or no use for the scientific publications available in those fields. Most agents are searching for domain-specific knowledge, with knowledge of other domains being regarded irrelevant and useless. Knowledge acquired in order to survive in polar regions is not expedient for nomads in a desert.

Even between scholars in the same discipline, communication can falter when individuals adhere to different thought styles or thought communities or do not have the discursive openness necessary to accept colleagues' new methods or theories. ${ }^{25}$

\footnotetext{
${ }^{24}$ International journals of the humanities and social sciences are full of monolingual lists of references, in spite of the fact that some of the most important publications of the relevant research field have been published in other languages.

25 " $[\mathrm{O}]$ nly in [discursive] openness are new truths able to emerge, truths that are not simply a yielding of one position to another, but a genuine preservation of the insight contained in either" (Ramberg \& Gjesdal, 2014, sec. 9, para. 6).
} 
"The greater the difference between two thought styles, the more inhibited will be the communication of ideas" (Fleck, 1935/1979, p. 109). In extreme cases, the thought style "constrains the individual by determining "what can be thought in no other way.' Whole eras will then be ruled by this thought constraint" (p. 99).

The organic exclusiveness of every thought commune goes hand in hand with a stylized limitation upon the problems admitted. It is always necessary to ignore or reject many problems as trifling or meaningless. Modern science also distinguishes "real problems" from useless "bogus problems." This creates specialized valuation and characteristic intolerance, which are features shared by all exclusive communities. (p. 104)

A thought style can influence the perception and interpretation of information and in extreme cases it can constrain, inhibit, and determine the way of thinking.

Under the influence of a thought style one cannot think in any other way. It also excludes alternative modes of perception. Accordingly, no proper communication can arise between different thought styles. A thought style functions at such a fundamental level that the individual seems generally unaware of it. It exerts a compulsive force upon his thinking, so that he normally remains unconscious both of the thought style as such and of its constraining character. Yet such a style can be revealed in practice by an examination of how it is applied. The existence of stable thought collectives suggests the presence of a rather permanent thought style. (Trenn \& Merton, 1979, p. 159)

The third filter for incoming information concerns orientation knowledge and spontaneous impulses. Orientation knowledge normally is equated with religious, cultural, and ideological knowledge. However, some theoretical concepts and paradigms used in scientific disciplines also prove to be based on prejudice, preconception, and jaundice. The obstinate adherence to a specific scientific paradigm or school of thought can entail the same detrimental effects as ideological prejudice. ${ }^{26}$ Orientation knowledge has a bearing on whether new information is emotionally or ideologically rejected, whether it is compatible with the recipient's self-perception, emotions, and identity. Information may be rejected because it questions the recipient's own research or thought style, because it shatters the reputation of a thought community, a scientific school, or scientific approach a person is associated with. Decisions to accept or repudiate new information may occur mindlessly or automatically; that is, "without directing much attention to the utility of an outcome, a person may act the way he or she has acted many times before" (Strack \& Deutsch, 2004, p. 220).

The dichotomy between factual knowledge and orientation knowledge can be enhanced by the dichotomy of reflexive and impulsive thought. In recent years, psychologists proposed that social behavior is the effect of two interacting systems of information processing or two modes of judgment - the reflective system and the impulsive system - that follow different operating principles (for an overview of the

\footnotetext{
${ }^{26}$ Followers of traditional neoclassical theory argued for decades that the homo oeconomicus acts in a more or less homogeneous space and has access to the information needed for rational decision-making. In the last 20 or 30 years, most of these ideas were largely discredited, not only in science studies, geography of knowledge, or actor-network theory, but also in evolutionary economics, behavioral economics, the concepts of bounded rationality, new theories of the firm, or the strategic management approach.
} 
literature see Krishna \& Strack, 2016; Smith \& DeCoster, 2000; Strack \& Deutsch, 2004, 2007). The reflective system is determined by deliberate thought and generates decisions that are based on knowledge about facts and values. It operates according to propositional principles; it is flexible, effortful, slow, requires motivation, and its operation is typically conscious. It is driven by working memory resources, which sets limits for its capacity for information processing. The impulsive system operates according to associative principles; it is inflexible, effortless, always active, and may operate unconsciously. The impulsive system can be seen as long-term memory and therefore has functionally unlimited capacity (Strack \& Deutsch, 2004, pp. 220-223; Krishna \& Strack, 2016).

The reflective system requires a high amount of cognitive capacity.... In contrast, the impulsive system requires little cognitive capacity and may control behavior under suboptimal conditions. As a consequence, processes of the reflective system are disturbed more easily than those of the impulsive system (Strack \& Deutsch, 2004, p. 223)

\section{Conclusion}

An in-depth model of the communication process between a source of knowledge and recipient of information is the foundation of any research about the mobility of different categories of knowledge. The spatial diffusion of knowledge depends both on the willingness of the producer to share his or her knowledge and the skills, experiences, and cognitive processes of the potential recipients of information. Research on knowledge-spillovers, knowledge-sharing, or territorial knowledge dynamics has focused more or less on successful cases of learning and knowledge exchange. It seldom asked the question why the diffusion of knowledge within clusters or networks failed.

This paper shows that the category, grade, and content of knowledge; the code and channels of transmission; the prior knowledge of potential recipients; and some other factors decide about the speed and target locations of the spatial diffusion of knowledge. It explains why large proportions of high-grade knowledge (certain scientific results) can only be spread to a small number of target locations. Only very simple, everyday low-grade knowledge can be communicated in a way that it reaches large parts of the world in a short period of time and at no or little cost. Even some types of low-grade knowledge can get lost at one of the steps of the communication model or not run unchanged through the communication process.

The communication model presented in this chapter can be extended by including the role and impact of institutional, cultural, and political contexts. Possible recipients of information are embedded in and influenced by different institutions, cultural contexts (Chen, Sun, \& McQueen, 2010; Lucas, 2006), knowledge environments (Meusburger, 2015b), KnowledgeScapes (Matthiesen, 2009, 2013), business ecologies (Grabher et al., 2008), networks (Glückler, 2007, 2013; Grabher \& Ibert, 2006), institutional logics (Battilana, 2006; Suddaby, Elsbach, Greenwood, Meyer, \& Zilber, 2010), citation cartels (Paasi, 2015), and, not to forget, world views and 
ideologies. Such institutions, contexts, or milieus may screen out certain information, show preferences for particular results, dispose taboos, exert censorship, and apply pressure on their members.

The model can be further amended by issues of how knowledge is legitimated; how individual knowledge becomes collective knowledge of an organization; how knowledge is transformed into organizational routines and structures; how the processing of information is modified by the presence of others; how the communication process is influenced by an organization's size and hierarchic structure; and to what extent knowledge governance "can influence the processes of using, sharing, integrating, and creating knowledge in preferred directions and towards preferred levels" (Foss et al., 2010, p. 456; see also Spender, 2005).

Acknowledgement I am grateful to David Antal for his elegant translation and editing of this chapter.

\section{References}

Abel, G. (2004). Zeichen der Wirklichkeit [Signs of reality]. Frankfurt am Main: Suhrkamp.

Amin, A., \& Cohendet, P. (2004). Architectures of knowledge: Firms, capabilities, and communities. Oxford: Oxford University Press.

Ancori, B., Bureth, A., \& Cohendet, P. (2000). The economics of knowledge: The debate about codification and tacit knowledge. Industrial and Corporate Change, 9, 255-287. doi:10.1093/ icc/9.2.255

Andrews, K. M., \& Delahaye, B. L. (2000). Influences on knowledge processes in organizational learning: The psychosocial filter. Journal of Management Studies, 37, 797-810. doi:10.1111/1467-6486.00204

Antweiler, C. (2016). Local knowledge as a universal social product: A general model and a case from Southeast Asia. In P. Meusburger, T. Freytag, \& L. Suarsana (Eds.), Ethnic and cultural dimensions of knowledge (pp. 165-190). Knowledge and Space: Vol. 8. Dordrecht: Springer. doi:10.1007/978-3-319-21900-4_8

Asheim, B. (2007). Differentiated knowledge bases and varieties of regional innovation systems. Innovation: European Journal of Social Science Research, 20, 223-241. doi:10.1080/13511610701722846

Battilana, J. (2006). Agency and institutions: The enabling role of individuals' social position. Organization, 13, 653-676. doi:10.1177/1350508406067008

Baumard, P. (1999). Tacit knowledge in organizations. London: Sage.

Bathelt, H., Malmberg, A., \& Maskell, P. (2004). Clusters and knowledge: Local buzz, global pipelines and the process of knowledge creation. Progress in Human Geography, 28, 31-56. doi:10.1191/0309132504ph469oa

Bathelt, H., \& Glückler, J. (2011). The relational economy: Geographies of knowing and learning. Oxford: Oxford University Press.

Blackler, F. (2002). Knowledge, knowledge work, and organizations: An overview and interpretation. In C. W. Choo \& N. Bontis (Eds.), The strategic management of intellectual capital and organizational knowledge (pp. 47-62). Oxford: Oxford University Press.

Breschi, S., \& Lissoni, F. (2001a). Knowledge spillovers and local innovation systems: A critical survey. Industrial and Corporate Change, 10, 975-1005. doi:10.1093/icc/10.4.975 
Breschi, S., \& Lissoni, F. (2001b). Localised knowledge spillovers vs. innovative milieux: Knowledge 'tacitness' reconsidered. Papers in Regional Science, 80, 255-273. doi:10.1111/j.1435-5597.2001.tb01799.x

Breschi, S., \& Malerba, F. (2001). The geography of innovation and economic clustering: Some introductory notes. Industrial and Corporate Change, 10, 817-833. doi:10.1093/icc/10.4.817

Butzin, A., \& Widmaier, B. (2016). Exploring territorial knowledge dynamics through innovation biographies. Regional Studies, 50, 220-232. doi:10.1080/00343404.2014.1001353

Cabrera, Á., Collins, W. C., \& Salgado, J. F. (2006). Determinants of individual engagement in knowledge sharing. International Journal of Human Resource Management, 17, 245-264. doi: $10.1080 / 09585190500404614$

Cairncross, F. (1997). The death of distance: How the communications revolution will change our lives. Boston: Harvard Business School Press.

Callon, M., Cohendet, P., Curien, N., Dalle, J. M., Eymard-Duvernay, F., Foray, D., \& Schenk, E. (1999). Réseau et coordination [Network and coordination]. Paris: Economica.

Chen, J., Sun, P.Y.T., \& McQueen, R. J. 2010). The impact of national cultures on structured knowledge transfer. Journal of Knowledge Management, 14, 228-242. doi:10.1108/13673271011032373

Cialdini, R. B. (2008). Turning persuasion from an art into a science. In P. Meusburger, M. Welker, \& E. Wunder (Eds.), Clashes of Knowledge. Orthodoxies and heterodoxies in science and religion (pp. 199-209). Knowledge and Space: Vol. 1. Dordrecht: Springer. doi:10.1007/978-1-4020-5555-3_12

Cohen, W. M., \& Levinthal, D. A. (1990). Absorptive capacity: A new perspective on learning and innovation. Administrative Science Quarterly, 35, 128-152. doi:10.2307/2393553

Cohendet, P., \& Steinmüller, W. E. (2001). The codification of knowledge: A conceptual and empirical exploration. Industrial and Corporate Change, 9, 195-209. doi:10.1093/icc/9.2.195

Collins, H. M. (1983). The sociology of scientific knowledge: Studies of contemporary science. Annual Review of Sociology, 9, 265-285. doi:10.1146/annurev.so.09.080183.001405

Collins, H. M. (2001). What is tacit knowledge? In T. R. Schatzi, K. Knorr Cetina, \& E. von Savigny (Eds.), The practice turn in contemporary theory (pp. 107-119). London: Routledge.

Cowan, R., David, P. A., \& Foray, D. (2000). The explicit economics of knowledge codification and tacitness. Industrial and Corporate Change, 9, 211-253. doi:10.1093/icc/9.2.211

Crevoisier, O. (2016). The economic value of knowledge: Embodied in goods or embedded in cultures? Regional Studies, 50, 189-201. doi:10.1080/00343404.2015.1070234

Crevoisier, O., \& Jeannerat, H. (2009). Territorial knowledge dynamics: From the proximity paradigm to multi-location milieus. European Planning Studies, 17, 1223-1241. doi:10.1080/09654310902978231

Fershtman, C., \& Gandal, N. (2011). Direct and indirect knowledge spillovers: The "social network" of open-source projects. RAND Journal of Economics, 42, 70-91. doi:10.1111/j.1756-2171.2010.00126.x

Fiedler, K., \& Wänke, M. (2009). The cognitive-ecological approach to rationality in social psychology. Social Cognition, 27, 699-732.

Fischer, M. M. (2001). Innovation, knowledge creation and systems of innovation. The Annals of Regional Science, 35, 199-216. doi:10.1007/s001680000034

Fischer, M. M., Scherngell, T., \& Jansenberger, E. (2006). The geography of knowledge spillovers between high technology firms in Europe: Evidence from a spatial interaction modelling perspective. Geographical Analysis, 38, 288-309. doi:10.1111/j.1538-4632.2006.00687.x

Fleck, L. (1979). Genesis and development of a scientific fact (F. Bradley \& T. J. Trenn, Trans.). Chicago: Chicago University Press. (Original work published in 1935). Retrieved from http:// www.evolocus.com/Textbooks/Fleck1979.pdf

Foss, N. J., Husted, K., \& Michailova, S. (2010). Governing knowledge sharing in organizations: Levels of analysis, governance mechanisms, and research directions. Journal of Management Studies, 47, 455-482. doi:10.1111/j.1467-6486.2009.00870.x 
Franck, G. (1998). Ökonomie der Aufmerksamkeit. Ein Entwurf [The economy of attention: A draft]. Munich: Hanser.

Froese, A., \& Mevissen, N. (2016). Fragmentierter Wissenstransfer der Sozialwissenschaften: Zur Relevanz disziplinenspezifischer Kontextfaktoren [Fragmented knowledge transfer of social sciences: The relevance of discipline-specific context factors]. In A. Froese, D. Simon, \& J. Böttcher (Eds.), Sozialwissenschaften und Gesellschaft. Neue Verortungen von Wissenstransfer (pp. 31-63). Bielefeld: transkript.

Fujita, M., Krugman, P. R., \& Venables, A. J. (1999). The spatial economy: Cities, regions, and international trade. Cambridge, MA: MIT Press.

Gadamer, H.-G. (1999). Truth and method. 2nd, revised edition (J. Weinsheimer \& D. G. Marshall, Trans.). New York: Continuum (Original work published in 1960).

Gertler, M. S. (2003). Tacit knowledge and the economic geography of context, or the undefinable tacitness of being (there). Journal of Economic Geography, 3, 75-99. doi:10.1093/jeg/3.1.75

Glückler, J. (2007). Economic geography and the evolution of networks. Journal of Economic Geography, 7, 619-634. doi:10.1093/jeg/lbm023

Glückler, J. (2013). Knowledge, networks and space: Connectivity and the problem of non-interactive learning. Regional Studies, 47, 880-894. doi:10.1080/00343404.2013.779659

Goddard, J. B. (1971). Office communications and office location: A review of current research. Regional Studies, 5, 263-280. doi:10.1080/09595237100185311

Goddard, J. B., \& Morris, D. (1976). The communications factor in office decentralization. Progress in Planning, 6, 1-80. doi:10.1016/0305-9006(76)90007-6

Goddard, J. B., \& Pye, R. (1977). Telecommunications and office location. Regional Studies, 11, 19-30. doi:10.1080/09595237700185031

Gottmann, J. (1980). Confronting centre and periphery. In J. Gottmann (Ed.), Centre and periphery: Spatial variation in politics (pp. 11-25). London: Sage.

Grabher, G., \& Ibert, O. (2006). Bad company? The ambiguity of personal knowledge networks. Journal of Economic Geography, 6, 251-271. doi:10.1093/jeg/lbi014

Grabher, G., Ibert, O., \& Flohr, S. (2008). The neglected king: The customer in the new knowledge ecology of innovation. Economic Geography, 84, 253-280. doi:10.1111/j.1944-8287.2008. tb00365.x

Gregory, D. (2000). Cultures of travel and spatial formations of knowledge. Erdkunde, 54, 297 319. http://www.jstor.org/stable/25647315

Henderson, J. V. (2007). Understanding knowledge spillovers. Regional Science and Urban Economics, 37, 497-508. doi:10.1016/j.regsciurbeco.2006.11.010

Huber, F. (2012). Do clusters really matter for innovation practices in Information Technology? Questioning the significance of technological knowledge spillovers. Journal of Economic Geography, 12, 107-126. doi:10.1093/jeg/lbq058

Jaffe, A. B., Trajtenberg, M., \& Henderson, R. (1993). Geographic localizations of knowledge spillovers as evidenced by patent citations. Quarterly Journal of Economics, 108, 577-598. Retrieved from http://www.jstor.org/stable/2118401

James, L., Vissers, G., Larsson, A., \& Dahlström, M. (2016). Territorial knowledge dynamics and knowledge anchoring through localized networks: The automotive sector in Västra Götaland. Regional Studies, 50, 233-244. doi:10.1080/00343404.2015.1007934

Jeannerat, H., \& Crevoisier, O. (2016). [Editorial] From 'territorial innovation models' to 'territorial knowledge dynamics': On the learning value of a new concept in regional studies. Regional Studies, 50, 185-188. doi:10.1080/00343404.2015.1105653

Karlsson, C., \& Manduchi, A. (2001). Knowledge spillovers in a spatial context. A critical review and assessment. In M. M. Fischer \& J. Fröhlich (Eds.), Knowledge, complexity and innovation systems (pp. 101-123). Advances in Spatial Science: Vol. 28. Heidelberg: Springer.

Krishna, A., \& Strack, F. (2017). Reflection and impulse as determinants of human behavior. In P. Meusburger, B. Werlen, \& L. Suarsana (Eds.), Knowledge and action (pp. 145-167). Knowledge and Space: Vol. 9. Dordrecht: Springer. doi:10.1007/978-3-319-44588-5_9

Knoke, K. (1996). Bold New World: The essential road map to the twenty-first century. New York: Kodansha. 
Lam, A. (2000). Tacit knowledge, organizational learning and societal institutions: An integrated framework. Organizational Studies, 21, 487-513. doi:10.1177/0170840600213001

Liebeskind, J. P. (1996). Knowledge, strategy, and the theory of the firm. [Special Issue] Strategic Management Journal, 17(S2), 93-107. doi:10.1002/smj.4250171109

Livingstone, D. N. (1995). The spaces of knowledge: Contributions towards a historical geography of science. Environment and Planning D: Society and Space, 13, 5-34. doi:10.1068/d130005

Livingstone, D. N. (2000). Making space for science. Erdkunde, 54, 285-296. doi:10.3112/ erdkunde.2000.04.01

Livingstone, D. (2002). Knowledge, space and the geographies of science. In D. N. Livingstone, Science, space and hermeneutics (pp. 7-40). Hettner-Lecture: Vol. 5. Heidelberg: Department of Geography.

Livingstone, D. N. (2003). Putting science in its place: Geographies of scientific knowledge. Chicago: University of Chicago Press.

Lucas, L. M. (2006). The role of culture on knowledge transfer: The case of the multinational corporation. The Learning Organization, 13, 257-275.

Mager, C. (2012). Heidelberg Nobel Prize winners. In P. Meusburger \& T. Schuch (Eds.), Wissenschaftsatlas of Heidelberg University. Spatio-temporal relations of academic knowledge production (pp. 250-253). Knittlingen: Bibliotheca Palatina.

Malmberg, A., \& Maskell, P. (2002). The elusive concept of localization economies: Towards a knowledge-based theory of spatial clustering. Environment and Planning A, 34, 429-449. doi:10.1068/a3457

Martin, R., \& Sunley, P. (2003) Deconstructing clusters: Chaotic concept or policy panacea? Journal of Economic Geography, 3, 5-35. doi:10.1093/jeg/3.1.5

Maskell, P., \& Malmberg, A. (1999). Localized learning and industrial competitiveness. Cambridge Journal of Economics, 23, 167-185. doi:10.1093/cje/23.2.167

Matthiesen, U. (2009). KnowledgeScapes: A new conceptual approach and selected empirical findings from recent research on knowledge milieus and knowledge networks. dis $P-$ The Planning Review, 177, 10-28. doi:10.1080/02513625.2009.10557032

Matthiesen, U. (2013). A new conceptual approach and selected empirical findings from research on knowledge milieus and knowledge networks. In P. Meusburger, J. Glückler, \& M. El Meskioui (Eds.), Knowledge and the economy (pp. 173-203). Knowledge and Space: Vol. 5. Dordrecht: Springer. doi:10.1007/978-94-007-6131-5_10

Meusburger, C. (2009). Cosmological measurements, time and observables in (2+1)-dimensional gravity. Classical and Quantum Gravity, 26, 055006, 1-32. doi:10.1088/0264-9381/26/5/055006

Meusburger, P. (1980). Beiträge zur Geographie des Bildungs- und Qualifikationswesens. Regionale und soziale Unterschiede des Ausbildungsniveaus der österreichischen Bevölkerung [Contributions to the geography of education and qualification: Regional and social disparities of the educational achievement of the Austrian population]. Innsbrucker Geographische Studien: Vol. 7. Innsbruck: Innsbruck University, Department of Geography.

Meusburger, P (1998). Bildungsgeographie. Wissen und Ausbildung in der räumlichen Dimension [Geography of education: Knowledge and education in the spatial dimension]. Heidelberg: Spektrum Akademischer Verlag.

Meusburger, P. (2000). The spatial concentration of knowledge: Some theoretical considerations. Erdkunde, 54, 352-364. doi:10.3112/erdkunde.2000.04.05

Meusburger, P. (2008). The nexus between knowledge and space. In P. Meusburger, M. Welker, \& E. Wunder (Eds.), Clashes of Knowledge. Orthodoxies and heterodoxies in science and religion (pp. 35-90). Knowledge and Space: Vol. 1, Dordrecht: Springer. doi:10.1007/978-1-4020-5555-3_2

Meusburger, P. (2009a). Milieus of creativity. The role of places, environments, and spatial contexts. In P. Meusburger, J. Funke, \& E. Wunder (Eds.), Milieus of creativity. An interdisciplinary approach to spatiality of creativity (pp. 97-153). Knowledge and Space: Vol. 2. Dordrecht: Springer. doi:10.1007/978-1-4020-9877-2_7 
Meusburger, P. (2009b). Spatial mobility of knowledge: A proposal for a more realistic communication model. disP-The Planning Review 177/2, 29-39. doi:10.1080/02513625.2009.10557033

Meusburger, P. (2013). Relations between knowledge and economic development: Some methodological considerations. In P. Meusburger, J. Glückler, \& M. El Meskioui (Eds.), Knowledge and the economy (pp. 15-42). Knowledge and Space: Vol. 5. Dordrecht: Springer. doi:10.1007/978-94-007-6131-5_2

Meusburger, P. (2015a). Relations between knowledge and power: An overview of research questions and concepts. In P. Meusburger, D. Gregory, \& L. Suarsana (Eds.), Geographies of knowledge and power (pp. 19-74). Knowledge and Space: Vol. 7. Dordrecht: Springer. doi:10.1007/978-94-017-9960-7_1

Meusburger, P. (2015b). Knowledge environments in universities. Hungarian Geographical Bulletin, 64, 265-279. doi:10.15201/hungeobull.64.4.1

Meusburger, P., Koch, G., \& Christmann, G. B. (2011). Nähe- und Distanz-Praktiken in der Wissenserzeugung. Zur Notwendigkeit einer kontextbezogenen Analyse [Proximity and distance practices in the generation of knowledge: The necessity of a context related analysis]. In O. Ibert \& H. J. Kujath (Eds.), Räume der Wissensarbeit. Zur Funktion von Nähe und Distanz in der Wissensökonomie (pp. 221-249). Wiesbaden: VS Verlag für Sozialwissenschaften.

Mintzberg, H. (1979). The structuring of organizations. A synthesis of the research. Englewood Cliffs: Prentice Hall.

Naisbitt, R. (1982). Megatrends: Ten new directions transforming our lives. New York: Warner Books.

Negroponte, N. (1995). Being digital. New York: Knopf.

Nonaka, I., \& Takeuchi, H. (1995). The knowledge-creating company. How Japanese companies create the dynamics of innovation. Oxford: Oxford University Press.

Nüsser, M., \& Baghel, R. (2016). Local knowledge and global concerns: Artificial glaciers as a focus of environmental knowledge and development interventions. In P. Meusburger, T. Freytag, \& L. Suarsana (Eds.), Ethnic and cultural dimensions of knowledge (pp. 191-209). Knowledge and Space: Vol. 8. Dordrecht: Springer. doi:10.1007/978-3-319-21900-4_9

Oinas, P., \& Malecki, E. (2002). The evolution of technology in time and space: From national and regional innovation systems to spatial innovation systems. International Regional Science Review, 25, 102-131. doi:10.1177/016001702762039402

Osterloh, M., \& Frey, B. (2000). Motivation, knowledge transfer, and organizational form. Organization Science, 11, 538-550. doi:10.1287/orsc.11.5.538.15204

Paasi, A. (2015). "Hot spots, dark-side dots, tin pots": The uneven internationalism of the global academic market. In P. Meusburger, D. Gregory, \& L. Suarsana (Eds.), Geographies of knowledge and power (pp. 247-262). Knowledge and Space: Vol. 7. Dordrecht: Springer. doi:10.1007/978-94-017-9960-7_12

Polanyi, M. (1967). The tacit dimension. Garden City: Doubleday.

Raditsch, L. (2012). European Molecular Biology Laboratory (EMBL). In P. Meusburger \& T. Schuch (Eds.), Wissenschaftsatlas of Heidelberg University. Spatio-temporal relations of academic knowledge production (pp. 288-289). Knittlingen: Bibliotheca Palatina.

Ramberg, B., \& Gjesdal, K. (2014). Hermeneutics. In E. N. Zalta (Ed.), The Stanford encyclopedia of philosophy. Retrieved from http://plato.stanford.edu/archives/win2014/entries/hermeneutics/ (Original work published 2005)

Reber, A. S. (1993). Implicit learning and tacit knowledge: An essay on the cognitive unconscious. Oxford Psychology Series: Vol. 19. New York: Clarendon Press.

Relph, E. (1976). Place and placelessness. London: Pion.

Schafmeier, T., Franke-Schaub, M., Schirmer, H., \& Brunner, M. (2012). Heidelberg University Biochemistry Center (BZH). In P. Meusburger \& T. Schuch (Eds.), Wissenschaftsatlas of Heidelberg University. Spatio-temporal relations of academic knowledge production (pp. 222224). Knittlingen: Bibliotheca Palatina. 
Scherngell, T. (2007). Interregionale Wissensspillovers in der europäischen High-Tech Industrie. Eine empirische Analyse [Inter-regional knowledge spillovers in the European high-tech industry]. Wiesbaden: Deutscher Universitäts-Verlag.

Seltmann, S. (2012). The German Cancer Research Center (DKFZ). In P. Meusburger \& T. Schuch (Eds.), Wissenschaftsatlas of Heidelberg University. Spatio-temporal relations of academic knowledge production (pp. 284-285). Knittlingen: Bibliotheca Palatina.

Senft, G. (2016). "Masawa-bogeokwa si tuta!": Cultural and cognitive implications of the Trobriand Islanders' gradual loss of their knowledge of how to make a Masawa canoe. In P. Meusburger, T. Freytag, \& L. Suarsana (Eds.), Ethnic and cultural dimensions of knowledge (pp. 229-256). Knowledge and Space: Vol. 8. Dordrecht: Springer. doi:10.1007/978-3-319-21900-4_11

Shera, J. H. (1970). Sociological foundations of librarianship. Mumbai: Asia Publishing House.

Short, J., Williams, E., \& Christie, B. (1976). The social psychology of telecommunication. London: Wiley.

Sillitoe, P. (2016). The knowing in indigenous knowledge: Alternative ways to view development, largely from a New Guinea Highlands' perspective. In P. Meusburger, T. Freytag, \& L. Suarsana (Eds.), Ethnic and cultural dimensions of knowledge (pp. 129-163). Knowledge and Space: Vol. 8. Dordrecht: Springer. doi:10.1007/978-3-319-21900-4_7

Smith, E. R., \& DeCoster, J. (2000). Dual process models in social and cognitive psychology: Conceptual integration and links to underlying memory systems. Personality and Social Psychology Review, 4, 108-131. doi:10.1207/S15327957PSPR0402_01

Spender, J. C. (2005). Review article: An essay of the state of knowledge management. Prometheus, 23, 101-116. doi:10.1080/0810902042000335732

Spinner, H. F. (1994). Die Wissensordnung: Ein Leitkonzept für die dritte Grundordnung des Informationszeitalters [Studies on the knowledge order: A concept to guide the third fundamental order of the information age]. Studien zur Wissensordnung: Vol. 1. Opladen: Leske \& Budrich.

Storper, M., \& Venables, A. J. (2004). Buzz: Face-to-face contact and the urban economy. Journal of Economic Geography, 4, 351-370. doi:10.1093/jnlecg/lbh027

Strack, F., \& Deutsch, R. (2004). Reflective and impulsive determinants of social behavior. Personality and Social Psychology Review, 8, 220-247. doi:10.1207/s15327957pspr0803_1

Strack, F., \& Deutsch, R. (2007). The role of impulse in social behavior. In A. W. Kruglanski \& E. T. Higgins (Eds.), Social psychology: Handbook of basic principles (revised and expanded 2nd ed., pp. 408-431). New York: Guilford Press.

Strassoldo, R. (1980). Centre-periphery and system boundary: Cultural perspectives. In J. Gottmann (Ed.), Centre and periphery: Spatial variation in politics (pp. 27-61). London: Sage.

Suddaby, R., Elsbach, K. D., Greenwood, R., Meyer, J. W., \& Zilber, T. B. (2010). Organizations and their institutional environments. Bringing meaning, values, and culture back in: Introduction to the special research forum. Academy of Management Journal, 53, 1234-1240. http://www. jstor.org/stable/29780257

Tichenor, P. J., Donohue, G. A., \& Olien, C. N. (1970). Mass media flow and differential growth in knowledge. The public opinion quarterly, 34, 159-170. Retrieved from http://www.jstor.org/ stable/2747414

Toffler, A. (1980). The third wave. New York: Bantam Books.

Tortoriello, M., Reagans, R., \& McEvily, B. (2012). Bridging the knowledge gap: The influence of strong ties, network cohesion, and network range on the transfer of knowledge between organizational units. Organization Science, 23, 1024-1039. doi:10.1287/orsc.1110.0688

Trenn, T, J., \& Merton, R. K, (1979). Descriptive analysis. In L. Fleck, Genesis and development of a scientific fact (pp. 154-165). Chicago: Chicago University Press.

Tsai, W. (2001). Knowledge transfer in intra-organizational networks. Academy of Management Journal, 44, 996-1004. doi:10.2307/3069443 
Vissers, G., \& Dankbaar, B. (2016). Spatial aspects of interfirm collaboration: An exploration of firm-level knowledge dynamics. Regional Studies, 50, 260-273. doi:10.1080/00343404.2014. 1001352

Wagner, R. K., \& Sternberg, R. J. (1987). Tacit knowledge in managerial success. Journal of Business and Psychology, 1, 301-312. doi:10.1007/BF01018140

Whitley, R. (1984a). The development of management studies as a fragmented adhocracy. Social Science Information, 23, 775-818. doi:10.1177/053901884023004007

Whitley, R. (1984b). The intellectual and social organization of the sciences. Oxford: Clarendon Press.

Willke, H. (1998). Organisierte Wissensarbeit [Organized knowledge work]. Zeitschrift für Soziologie, 27, 161-177. Retrieved from http://www.zfs-online.org/index.php/zfs/article/ viewFile/2971/2508

Open Access This chapter is distributed under the terms of the Creative Commons Attribution 4.0 International License (http://creativecommons.org/licenses/by/4.0/), which permits use, duplication, adaptation, distribution and reproduction in any medium or format, as long as you give appropriate credit to the original author(s) and the source, provide a link to the Creative Commons license and indicate if changes were made.

The images or other third party material in this chapter are included in the work's Creative Commons license, unless indicated otherwise in the credit line; if such material is not included in the work's Creative Commons license and the respective action is not permitted by statutory regulation, users will need to obtain permission from the license holder to duplicate, adapt or reproduce the material. 